\title{
DETERMINANTS OF INCOME SMOOTHING IN MINING ISSUERS LISTED ON THE INDONESIA STOCK EXCHANGE
}

\author{
Maharani I.A.D.P. ${ }^{*}$, Putra I G.B.N.P. \\ Faculty of Economics and Business, Warmadewa University, Indonesia \\ *E-mail: iadindapriyanka@gmail.com
}

\begin{abstract}
Financial statements have an important role in the decision-making process. One component of financial statements that describes the performance of issuers is the profit component. Any changes related to earnings information will affect the actions of investors. One example of changes in earnings components is earnings management (income smoothing). There are several factors that cause the practice of income smoothing including profitability (ROA) and leverage (DER). The inconsistency of research results that examine the effect of ROA and DER on income smoothing practices indicates that previous research has not been conclusive, thus encouraging researchers to conduct further research. This research was conducted on issuers of the mining sector listed on the Indonesia Stock Exchange from 2018 to 2020. The population of this study was issuers in the mining sector listed on the Indonesia Stock Exchange for the period 2018-2020 as many as 47 companies. The sampling method used in this study was purposive sampling method so that a sample of 30 issuers was obtained with a total of 90 observations. The type of data used in this study is quantitative data, and the source of data used in this study is secondary data. The data collection technique used in this research is through the documentation method. The data analysis technique used in this research is multiple linear regression analysis. The results show that the ROA variable has a significant negative effect on the practice of income smoothing, while the DER variable has a significant positive effect on the practice of income smoothing.
\end{abstract}

\section{KEY WORDS}

Income smoothing, return on asset ratio, debt to equity ratio.

Stakeholders, especially investors, make the issuer's business performance a benchmark in investing. Investors who are classified as sophisticated will not invest their funds carelessly in companies that perform poorly. The choice will be on issuers that have good fundamental performance, when investors are faced with long-term investment goals.

Financial statements are very crucial in their function and existence for stakeholders because financial statements are a form of management's responsibility to the owner for business management. Financial statements can also be a tool to assess business performance over the last several periods. As well as being the basis for making predictions and projections of future business performance.

One component of financial statements that describes the performance of issuers is the profit component. In general, the amount of profit can be a decision maker for investors. Any changes related to earnings information will affect the actions of investors. One example of changes in earnings components is earnings management. Earnings management actions can mislead stakeholders, especially investors because the financial statements presented do not describe the real situation.

There are several types of earnings management, including income maximization, income minimization, taking a bath, and income smoothing. This study focuses on income smoothing because the pattern of earnings management is most often done by reporting earnings in a period so that it is not too much different from the earnings of the previous period. The reason for doing income smoothing is to increase the value of the company and convince investors that the issuer has a low risk, so that the issuer's share price will increase. 
Another objective is to obtain opportunistic personal benefits such as obtaining bonuses or promotions.

Agency theory can explain the phenomenon of income smoothing. The existence of a conflict of interest between the agent and the principal plus the difference in information (information asymmetry) owned by both parties is the reason for doing income smoothing. Owners are more focused on the amount of profit, while management wants compensation, bonuses or promotions. This encourages management to perform income smoothing, namely because owners prefer relatively stable profits compared to fluctuating profits.

In this study, the researcher focuses on the effect of profitability and leverage on the occurrence of income smoothing practices. The reason for choosing the profitability ratio in this study is because large investor attention and only focusing on the profit component (profitability) can encourage management to smooth earnings. When the profitability of the issuer is low, management tends to do income smoothing. While the reason for testing the leverage ratio is because the leverage ratio reflects the company's debt ratio. The greater this ratio, the worse the company's image in the eyes of investors, because the company is at great risk. To overcome this, the company will try to increase its profits by doing income smoothing. The aim is to improve the reputation and view of investors towards the company so that it is able to attract investors to invest.

The profitability ratio is measured using ROA (Return on Asset Ratio). The reason for using $R O A$ as a proxy in measuring profitability ratios is because ROA describes the effectiveness and efficiency of issuers in managing their assets in order to generate profits. For investors, indicators of business attractiveness and the issuer's ability to generate profits can be assessed from the level of profitability, namely ROA.

Meanwhile, the leverage ratio is measured by the DER (Debt to Equity Ratio) proxy. The DER ratio describes the availability of capital in guaranteeing the company's debt. These two components of financial statements are of concern to investors because if the amount of debt is greater than the capital, the issuer is classified as high risk and reduces investor interest in investing.

Research that examines the effect of profitability ratios, especially Return on Assets on income smoothing practices, obtains mixed results. For example, research conducted by Hastiti (2017) and Mahendra and Jati (2020) which found results that the profitability variable (Return on Assets) had a positive effect on income smoothing practices. Meanwhile, research conducted by Carolline and Linda (2020) obtained the results that the profitability ratio (Return on Assets) had a negative effect on the practice of income smoothing. Furthermore, research from Putri (2008) and research from Ryanto and Sundari (2020) found different results, namely the profitability variable (Return on Assets) had no effect on income smoothing practices. Different results were also obtained by Wijoyo (2014) and Fatmawati and Djajanti (2015) who found the results that the profitability variable (Return on Assets) had an effect on the practice of income smoothing.

Meanwhile, studies that examine the effect of leverage ratios, especially the Debt to Equity Ratio on income smoothing practices, also get mixed results from one another. Like the research conducted by Hastiti (2017) which found the results that the leverage variable, especially the Debt to Equity Ratio, had a positive effect on the practice of income smoothing. Meanwhile, research conducted by Carolline and Linda (2020) found that the leverage variable, especially the Debt to Equity Ratio, had a negative effect on the practice of income smoothing. Furthermore, research from Wijoyo (2014) and research from Isdayanti and Sari Pujiana (2017) found different results, namely the leverage variable, especially the Debt to Equity Ratio, had no effect on the practice of income smoothing. Different results were also obtained by Putri (2008) and Wijaya (2009) who found the results that the leverage variable, especially the Debt to Equity Ratio, had an effect on the practice of income smoothing.

Through the explanation above, it can be seen that there are still inconsistencies in the results which become research gaps. This indicates that the results of previous studies are not conclusive and encourage further research. In addition to the previous research gap research, one of the important keys in this research is the existence of a state of the art. The 
majority of previous studies used issuers in the manufacturing sector as the research sample. The thing that distinguishes or the state of the art of this research is the use of research samples, namely issuers in the mining sector. The aim is to increase the repertoire of research results related to the determinants of income smoothing practices.

\section{LITERATURE REVIEW}

Agency theory is a theory that can describe the practice of income smoothing. Agency theory explains the agency conflict that occurs between the management (agent) and the principal (investor/owner). Furthermore, in agency theory it is stated that there is a difference in information (information asymmetry) between the agent and the principal. The agent as a business manager has more information than the principal. Information held by company management can trigger actions in accordance with the interests and desires to achieve prosperity (Mursalim, 2005). Meanwhile, it will be difficult for investors to control the opportunistic actions that have been carried out by the company's management due to limited information. One example of opportunistic actions from the management is income smoothing.

The difference in information held by the agent and principal underlies the emergence of signaling theory. Signaling theory can be defined as a company management step that actually provides implicit instructions to investors about how management views the company's prospects (Steven and Lina, 2011). These instructions become a sign related to the stability of the company's performance, the company's profit each year, for example, from a profit perspective. The profit presented in the financial statements is the actual profit or is the result of income smoothing practices.

\section{RESEARCH HYPOTHESIS}

The Effect of Return on Asset Ratio (ROA) on Income Smoothing Practices. Companies that have fluctuating profitability tend to perform income smoothing (Juniarti and Carolina, 2005). This indicates that the impact of profit fluctuations will be more severe in companies that have low profitability. Investors will also be afraid of fluctuations in profits with low profitability. According to Wijoyo (2014) that a stable level of profitability can attract investors to invest their capital. When the profitability of the issuer is low, management tends to do income smoothing.

H1: Return on Asset Ratio has a significant negative effect on the practice of Income Smoothing.

The Effect of Debt to Equity Ratio (DER) on Income Smoothing Practices. According to Fatmawati and Atik (2015), if the leverage ratio increases or is high (debt funding is increasing), it is difficult for the company to obtain additional loan funds because of concerns about the company's inability to cover its debts so that management will smooth out profits because the company is threatened with default. . Furthermore, the greater the DER ratio, the worse the company's image in the eyes of investors, because the company is at high risk. To overcome this, the company will try to increase its profits by doing income smoothing. In addition, Widana and Yasa (2013) state that although debt means risk, it also provides the potential to increase profits for the owner. Therefore, the company will try to do income smoothing.

H2: Debt to Equity Ratio has a significant positive effect on the practice of Income Smoothing.

\section{METHODS OF RESEARCH}

This research was conducted on mining sector issuers listed on the Indonesia Stock Exchange from 2018 to 2020. Data related to mining sector issuers was obtained by accessing the official website of the Indonesia Stock Exchange, namely www.idx.co.id. The population of this study is issuers in the mining sector listed on the Indonesia Stock 
Exchange for the $2018-2020$ period as many as 47 companies. The sampling method used in this study was purposive sampling method, so that the number of samples obtained was 30 samples during 2018 to 2020 and 90 observations were obtained. The data collection technique used in this research is through the documentation method. The hypothesis test used is multiple linear regression tests.

\section{RESULTS OF STUDY}

Based on the results of the analysis in Table 1, it can be seen that the average value of the variables, both the dependent variable and the independent variable, has a value greater than the standard deviation, which indicates that the data is well distributed.

Table 1 - Descriptive Statistical Results of ROA, DER, and Income Smoothing Practices on Indonesian Stock Exchange Mining Sector Companies in 2018-2020

Descriptive Statistics

\begin{tabular}{|l|l|l|l|l|l|}
\hline & N & Minimum & Maximum & Mean & Std. Deviation \\
\hline ROA & 30 & -.25 & .21 & .0300 & .09505 \\
DER & 30 & .16 & 4.75 & 1.4353 & 1.15283 \\
IS & 30 & -5.923646 & 5.371516 & -.35776313 & 2.392041713 \\
Valid N (listwise) & 30 & & & & \\
\hline
\end{tabular}

Table 2 - Simple Linear Regression Analysis

\begin{tabular}{llllll}
\hline \multirow{2}{*}{ Variabel } & \multicolumn{2}{l}{ Unstandardized coefficient } & Standardized coefficient & \multirow{2}{*}{ t-hitung } & \multirow{2}{*}{ Sig. } \\
\cline { 2 - 5 } & $\mathrm{B}$ & Std. Error & Beta & $-2,795$ & 0,009 \\
\hline Constant & $-1,725$ & 0,617 & - & $-2,162$ & 0,040 \\
$\mathrm{X}_{1}(\mathrm{ROA})$ & $-8,580$ & 3,968 & $-0,341$ & 3,459 & 0,002 \\
$\mathrm{X}_{2}$ (DER) & 1,132 & 0,327 & 0,545 & & \\
\hline $\mathrm{R}$ & 0,827 & & & \\
Adjusted R Square & 0,661 & & & \\
F $_{\text {hitung }}$ & 29,273 & & & \\
Sig F & 0,000 & &
\end{tabular}

Source: Processed data (2021).

Multiple Linear Regression Determination Coefficient Test. Based on Table 2, it can be seen that the value of Adjusted $R$ Square is 0.661 , which means 66.1 percent of the dependent variable Income Smoothing can be explained by the ROA and DER variables while the remaining 33.9 percent is influenced by other variables that are not included in this research model.

Model Feasibility Test ( $F$ Test). Based on the $F$ test carried out in Table 2, the calculated $F$ is 29.273 with a significance level of 0.000 which is smaller than $\alpha=0.05$. Thus, this research model is suitable to be used to prove the formed hypothesis or in other words the fit model.

Regression Coefficient Test ( $t$ Test). The t-test was used to determine the effect of the independent variable on the dependent variable. If sig $<0.05$ then the independent variable has an effect on the dependent variable.

From the test results obtained data as in Table 2 where the value of the regression coefficient for the ROA variable is -0.8580 with a significance level of 0.040 , which is less than 0.05 . This means that ROA has a significant negative effect on income smoothing practices, so the first hypothesis is accepted.

Meanwhile, for testing the $\mathrm{X} 2$ variable, the result is that the regression coefficient value for the DER variable is 1.132 with a significance level of 0.002 , which is less than 0.05 . This means that DER has a significant positive effect on income smoothing practices, so the second hypothesis is accepted. 
Multiple Linear Regression Analysis. To determine the effect of ROA and DER variables on income smoothing practices, a simple linear regression statistical analysis was carried out. It can be seen that the regression coefficients for the ROA and DER variables are -0.850 and 1.132 , respectively, while the constant value is -1.725 , so a simple linear regression equation is obtained as follows:

$$
Y=-1.725-8.580 X 1+1.132 X 2+e
$$

Based on the regression equation model, the following information can be explained:

- The constant value of -1.721 means that if the ROA and DER variables are considered constant or equal to 0 (zero), then the income smoothing practice has a value of -1.721 ;

- The ROA coefficient value is $\beta_{1}=-8,580$ with a significance level of 0.040 , meaning that if there is an increase in the ROA variable by 1 unit, the income smoothing variable will decrease by -0.850 with the assumption that the other independent variables are constant;

- The value of the DER coefficient is $\beta_{2}=1.132$ with a significance level of 0.002 , meaning that if there is an increase in the DER variable by 1 unit, the income smoothing variable will increase by 1.132 with the assumption that the other independent variables are constant.

\section{DISCUSSION OF RESULTS}

The Effect of Return on Asset Ratio (ROA) on Income Smoothing Practices. Based on the results of multiple linear regression analysis shows that the first hypothesis is accepted. This can be seen from the significance value of 0.040 , which is smaller than the specified significant level $(\alpha=0.05)$ and has a regression coefficient of -8.580 . Furthermore, the direction of the regression coefficient is in line with the hypothesis formed, so it can be concluded that the Return on Assets (ROA) Ratio variable has a negative and significant effect on income smoothing practices in mining sector issuers listed on the Indonesia Stock Exchange.

The presentation of statistical test results can be interpreted that the company will tend to minimize profits by practicing income smoothing when the company obtains a high level of profitability, and vice versa. The goal is to make the company's performance look more stable, because stable profits show better company performance compared to fluctuating profits. Furthermore, Wijoyo (2014) states that a stable level of profitability can attract investors to invest their capital. In addition, the large level of fluctuations in a company's earnings has the potential to be increasingly in the public spotlight, so that management tends to practice earnings management in the form of income smoothing.

The results of this study are in line with research from Ramdani (2012), Suryandari (2012) Natalie and Astika (2016), Alexandri and Anjani (2016) and Obaidat (2017) which prove that there is a negative and significant influence between profitability (ROA) on smoothing practices. profit (income smoothing).

The Effect of Debt to Equity Ratio (DER) on Income Smoothing Practices. Based on the results of multiple linear regression analysis shows that the second hypothesis is accepted. This can be seen from the significance value of 0.002 , which is smaller than the specified significant level $(\alpha=0.05)$ and has a regression coefficient of 1.132. Furthermore, the direction of the regression coefficient is in line with the hypothesis formed, so it can be concluded that the variable Debt to Equity Ratio (DER) has a positive and significant effect on income smoothing practices in mining sector issuers listed on the Indonesia Stock Exchange.

The presentation of the statistical test results can be interpreted that the higher the Debt to Equity Ratio (DER) variable, the higher the income smoothing practice. The greater the Debt to Equity Ratio (DER), the worse the company's image in the eyes of investors, because the company is at high risk. Therefore, a high Debt to Equity Ratio (DER) can 
reduce investor interest in investing in the company in question. To overcome this, the company will try to increase its profits by doing income smoothing. The aim is to improve the reputation and view of investors towards the company so that it is able to attract investors to invest. The results of this study are in line with research conducted by Manukaji and Juliana (2018) which states that financial leverage has a positive and significant effect on the practice of income smoothing.

\section{CONCLUSION}

Based on the results of the analysis and discussion that has been carried out, it can be concluded that:

- Return on Assets (ROA) Ratio has a negative and significant effect on income smoothing practices in mining sector issuers listed on the Indonesia Stock Exchange. This result means that the company will tend to minimize profit by practicing income smoothing when the company obtains a high level of profitability. And vice versa, where when the profitability of the issuer is low, the management tends to practice income smoothing;

- Debt to Equity Ratio (DER) has a positive and significant effect on income smoothing practices in mining sector issuers listed on the Indonesia Stock Exchange. This result means that the higher the Debt to Equity Ratio (DER) variable, the higher the practice of income smoothing.

\section{LIMITATIONS AND SUGGESTIONS}

The results obtained in this study have limitations where the observations are only limited to issuers in the mining sector, so the results cannot be generalized. For further research, it is possible to examine other sectors or all issuers listed on the Indonesia Stock Exchange. The next limitation is that the proxies used in this study are only the Return on Asset Ratio (Profitability Ratio) and Debt to Equity Ratio (Leverage Ratio). Subsequent research can use other proxies such as Return on Investment, Return on Equity for profitability ratios and Debt to Asset Ratios, and profit margins for leverage ratios.

\section{REFERENCES}

1. Alexandri, M. B., \& Anjani, W. K. 2016. Income smoothing: impact factors, evidence in Indonesia. International Journal of Small Business and Entrepreneurship Research, 3(1), 21-27.

2. Carolline. Linda Santioso. 2020. Pengaruh Financial Leverage, Profitability and Cash Holding Terhadap Income Smoothing. Jurnal Multiparadigma Akuntansi Tarumanagara. Vol.2 Edisi Juli 2020 : $1353-1361$

3. Fatmawati. Djajanti, A. 2015. Pengaruh Ukuran Perusahaan, Profitabilitas, and Financial Leverage Terhadap Praktik Perataan Laba Pada Perusahaan Manufaktur Yang Terdaftar Di Bursa Efek Indonesia. Jurnal Institut Perbanas Jakarta, ISSN : 2337-5965.

4. Ghozali, I. 2009. Aplikasi Analisis Multivariate dengan program SPSS. Semarang: Badan Penerbit Universitas Diponegoro.

5. Hastiti, Rini Tri. 2017. Faktor Yang Mempengaruhi Income Smoothing Pada Perusahaan Manufaktur Di BEI Tahun 2013-2015. Jurnal Ekonomi. Volume XXII, No. 03, Hal: 366373.

6. Isdayanti, Winda. Saripujiana, Dian. 2017. Pengaruh Financial Leverage and Debt Of Equity Terhadap Income Smoothing Pada Perusahaan Manufaktur Yang Terdaftar Di Bursa Efek Indonesia Periode 2012-2014. Jurnal Akuntansi and Manajemen Madani. Vol. 1 No. 2. 
7. Mahendra, P. R., and Jati, I Ketut. 2020. Pengaruh Ukuran Perusahaan, DER, ROA, and Pajak Penghasilan terhadap Praktik Income Smoothing. E-Jurnal Akuntansi. Vol. 30 No. 8.

8. Mahmud, Alam. 2012. Relationship between Interest Rate and Stock Price Empirical Evidence from Developed and Developing Countries. Vol.4 No.3 Department of Business Administration East West University.

9. Manukaji, I. J. (2018). Corporate Governance and Income Smoothing in the Nigerian Deposit Money Banks.

10. Mursalim. 2005. "Income Smoothing and Motivasi Investor: Studi Empiris pada Investor di Bursa Efek Jakarta". SNA VIII. September, Solo.

11. Natalie, N., \&Astika, I. B. P. (2016). Pengaruh Cash Holding, Bonus Plan, Reputasi Auditor, Profitabilitas and Leverage pada Income Smoothing. E-Jurnal Akuntansi, 943-972.

12. Nejad, H. S., Zeynali, S., \&Alavi, S. S. (2013). Investigation of Income Smoothing at The Companies Listed on The Stock Exchange by The Using Index Eckel (Case Study: Tehran Stock Exchange). Asian Journal of Management Sciences and Education, 2(2), 49-62.

13. Obaidat, A. N. (2017). Income Smoothing Behavior at the Times of Political Crises. International Journal of Academic Research in Accounting, Finance and Management Sciences, 7(2), 1-13.

14. Parsaoran, David. 2009. Skandal Manipulasi Laporan Keuangan PT. Kimia FarmaTbk. (http://davidparsaoran's. blogspot.com/ diakses tanggal 01 Februari 2021).

15. Putri, Herikaningsih Angkasa. 2008. Analisis Pengaruh Faktor Ukuran Perusahaan, Profitabilitas and Leverage Terhadap Income Smoothing: Studi Empiris Pada Perusahaan Manufaktur Yang Listing Di BEl. Skripsi thesis, Sanata Dharma University.

16. Ramdani, Dedi. 2012. Analisa Faktor-Faktor yang Mempengaruhi Income Smoothing pada Perusahaan Manufaktur Sektor Industri Logam di BEl. Skripsi Fakultas Ekonomi Universitas Gunadarma.

17. Ryanto, F. R., and Sundari, M. T. 2020. Pengaruh Ukuran Perusahaan, Return on Asset Ratios Terhadap Income Smoothing dengan Harga Saham Sebagai Variabel Moderating pada Perusahaan Manufaktur yang Terdaftar di BEl. Jurnal Produktivitas. Vol. 7 No. 1.

18. Steven and Lina. (2011). Faktor-faktor yang Mempengaruhi Kebijakan Hutang Perusahaan Manufaktur. Jurnal Bisnis and Akuntansi, 13 (3), 163-181.

19. Sugiono. 2010. Metode Penelitian Bisnis. Cetakan Ke-15. Bandung: CV. Alvabeta.

20. Suryandari. 2012. Analisis faktor-faktor yang mempengaruhi income smoothing. Media Komunikasi FIS, 11(1): h:11-15.

21. Wijaya, Mulyawati. 2009. Analisis Praktik Perataan Laba pada Industri Real Estate and Properti yang Bereputasi Baik di Bursa Efek Indonesia. Jurnal Akuntansi Kontemporer. Vol. 1 No. 2.

22. Wijoyo, Dewi Sari. 2014. Variabel-Variabel yang Mempengaruhi Praktik Perataan Laba Pada Perusahaan Manufaktur yang Publik. Vol. 16 No 1. 